\title{
Evolution of meteorological factors on incidence of red spider mite of tea, Oligonychus coffeae (Nietner) under the natural conditions of Assam
}

\section{DINESH KACHHAWA AND SAHIDUR RAHMAN}

Article Chronicle : Received: 04.12.2013;

Revised : 17.03.2015; Accepted : 08.04.2015

\begin{abstract}
The incidence of red spider mite, Oligonychus coffeae on tea crop was maximum during the month of April to May-June and September-October (2011). The minimum number of mites were recorded from July- August and November (2011) to February (2012). The data taken from $1^{\text {st }}$ week of April, 2011 to last week of March, 2012. That population build up of $O$. coffeae showed a significant positive correlation with the maximum temperature and minimum temperature $(r=0.320$ and $r=0.268$, respectively). Whereas, the red spider mite population was negatively correlated but significant with average relative humidity $(\mathrm{r}=-0.357)$. Rainfall had a negative non-significant correlation with the mite population $(r=-0.049)$.

How tO CITE THIS ARTICLE : Kachhawa, Dinesh and Rahman, Sahidur (2015). Evolution of meteorological factors on incidence of red spider mite of tea, Oligonychus coffeae (Nietner) under the natural conditions of Assam. Asian J. Environ. Sci., 10(1): 7-12.
\end{abstract}

Key Words : Red spider mite (Oligonychus coffeae), Incidence, Meteorological factors
Author for correspondence :

DINESH KACHHAWA

Department of

Entomology, Assam

Agriculture University,

JORHAT (ASSAM) INDIA

See end of the article for

Coopted authors' 